\title{
Prevalence of domestic violence against women and its risk factors in Gunma, Japan
}

\author{
Kazumi FUJIMURA ${ }^{1}$, Tohru YOSHIDA ${ }^{2}$, Takeshi YAMAMOTO ${ }^{3}$ \\ and Yoshihiko YAMAZAKI ${ }^{1}$
}

This study investigated the demographic characteristics of and factors related to men's violence against women in intimate relationships with the goal of learning how women can better cope with domestic violence. Of the adult residents of Gunma Prefecture, 888 (491 women and 397 men) were surveyed regarding domestic violence. Findings were as follows. 1) $30.1 \%$ reported experiencing abuse at least once in the 12 months preceding the survey. Emotional abuse was reported by $29.6 \%$ of female respondents, physical abuse by $5.4 \%$ and sexual abuse by $6.2 \%$. These rates are approximately the same as the proportion of men who reported abusing women. 2) Physical and/or sexual abuse is frequently accompanied by emotional abuse. 3) Men reporting tolerant attitudes towards violence tended to abuse women more ; those, regardless of sex, with a history of exposure to an environment of family abuse as children were more likely to suffer abuse as adults. 4) Half of the abused women had sought help by consulting others. Few of these women consulted organizations or public institutions ; instead, most women seeking help merely discussed their situation with family members, friends or colleagues. More counseling centers, shelters, and other forms of social support are required, and individual women should have better access to information on this topic. Moreover, it is essential that the public at large better understands the issue of domestic violence against women.

Key words : abuse, domestic violence, intimate partner, social support, violence against women

\section{Introduction}

Violence against women by intimate partners is a serious concern of modern society. The issue of domestic violence (DV) against women has yet to be dealt with openly in Japan due to the private nature of intimate relationships. However, with the rise of feminism in Europe and the United States in the mid-1970s, the anti-domestic violence movement grew (Schechter, 1982), and research has been conducted on the issue. As a result, DV was identified as a serious issue in modern society requiring intervention and prevention (World Bank, 1993).

In 1995, a declaration of principles regarding "Reproductive Health/Rights for Women" was adopted at the Fourth World Conference on Women (WCW) in Beijing, China. At this forum, violence against women was understood as a violation of human rights from an international point of

\footnotetext{
${ }^{1}$ Department of Health Sociology, School of Health Sciences and Nursing, Graduate School of Medicine, The University of Tokyo

${ }^{2}$ Gunma University School of Health Sciences

${ }^{3}$ Department of Health Science, School of Nursing, Chiba University
} 
view. In a number of countries, socio-pathological research has been conducted to clarify the social factors leading to violence and to construct theories explaining the phenomenon (Heise, 1998; Dutton, 1995a ; Dutton, 1995b ; Yllö, 1993 ; Gelles, 1993 ; Berkowitz, 1993 ; Walker, 1994 ; Bandura, 1977).

Japan barely recognized DV as a serious social problem before the WCW (Tokuza, 1999 ; Yoshihama, 2002), but thereafter has received more attention. In the "Gender-Equality Society Plan 2000" implemented by the Prime Minister's Office in 1996, guidelines were established to deal with violence against women. In 2001, Japan's first DV law, "The Law on Prevention of Spouse Violence and Protection of Victims" came into force. Baseline surveys (Tokyo Metropolitan Government, 1998 ; Japan Prime Minister Office, 2000) to evaluate the DV situation in Japanese society have been conducted by the municipal authorities and/or feminist organizations.

Although DV has been well studied in many areas worldwide, sufficient information is still not available for a complete understanding of the problem and its alleviation. For example, a study has been conducted to estimate the lifetime prevalence of abuse among women (Krahe et al., 2005), but neither the frequency nor the demographics of DV within limited time periods has been clarified (Bensley et al., 2003). Moreover, there have been methodological problems, such as considering the identification of a single episode of violence as confirmation of DV. It is necessary to evaluate the efficacy of techniques for prevention and intervention through time period-specific surveys. A number of factors correlating with the presence of violence have been identified. European and U.S. studies have reported that men with a traditional view of gender roles tend to be abusive (Straus and Gelles, 1990 ; Telch and Lindquist, 1984 ; Straus, 1978), while women with a traditional view of marriage tend to be abused (Straus and Gelles, 1986 ; Walker, 1979). One factor that keeps DV unnoticed is women's reluctance to talk about their DV experiences with people close to them (Rosenbaum and O'Leary, 1981 ; Umberson et al., 1998). Also, it has been found that "intergenerational chains of abuse" can originate from being raised in a family with domestic violence or from personal history of experiencing child abuse (Dutton, 1995c ; Dutton et al., 1996 ; Beasley and Stoltenberg, 1992 ; Rosenbaum and O'Leary, 1987 ; Kantor and Straus, 1989 ; Caesar, 1988 ; Fitch and Papantonio, 1983). These factors are important in terms of planning for prevention of DV and implementing interventions. It is important to learn how women have actually responded to or coped with DV in order to provide effective support of victims.

In Japan, most DV-related statistics (Tokyo Metropolitan Government, 1998 ; Office of the Japanese Prime Minister Office, 2000) do not include detailed data on the type or degree of abuse. Also, results of some research describing factors related to DV (Domestic Violence Action and Research Group in Japan, 1998) are similar to those of Western studies. However, clarifying these factors related to DV cannot be done because statistical tests are not employed. In addition, data obtained through Western research cannot be directly applied to the Japanese context since the Japanese cultural, social and legal background is very different from that in Western countries. Thus, research in Japan on the social context of DV is needed.

The purpose of this study was (1) to clarify the frequency and demographics of DV against women in Japan from both women and men's perspectives, (2) to examine psycho-sociological factors that relate to the frequency of DV, and (3) to present victims' responses by the pattern of $\mathrm{DV}$. 


\section{Methods}

\section{Participants and Procedure}

Data were collected from a questionnaire prepared by the Committee on Violence against Women in Gunma Prefecture, Japan. Study subjects were male and female residents of Gunma Prefecture, aged 18-74 years. A stratified twostage random sampling method was employed using the Basic Resident Registers of the involved municipalities to identify a potential sample group of 1,494,889 residents. On September 6, 2001, we mailed anonymous questionnaires for self-administration to 2,000 randomly selected subjects (980 women and 1,020 men) from this potential sample group and analyzed the questionnaires that were returned by mail between September 10 and 24, 2001. We received completed questionnaires from 888 subjects ( 491 women and 397 men), yielding a response rate of $50.1 \%$ for women and $38.9 \%$ for men. The data-gathering portion of the research was conducted by the Committee on Violence against Women in Gunma Prefecture, and the data obtained were examined by the authors for the purpose of the present research.

\section{Measures}

1) Subject Demographics

The questionnaire elicited information on subjects' social and demographic characteristics, such as age, employment status, and marital status, household type, etc. (Table 1).

2) Dependent Variables

Details of Abusive Behavior. The questionnaire was divided into 3 categories of emotional, physical and sexual abuse ; with 9, 7and 3 items (total 19), respectively. On the questionnaires sent to men, the following 2 items were omitted : II injured my wife/girlfriend with a weapon" and "My wife/ girlfriend's injury that I caused required medical attention". This decision was based on previous research suggesting that receiving honest answers to these questions is less likely from the abuser than from the victim (Pence and Paymar, 1993 ; Dutton, 1986 ; Dutton and Hemphill, 1992). A 3point response scale of "None", "Once or twice" and "Frequently" was employed. Responses were sought related to experiences with DV in the 12 months preceding the survey, and, additionally, for comparison with previous research, regarding any previous (lifetime) DV experience.

3) Independent Variables (Table 2)

(1) Socio-Demographic Characteristics of Intimate Partner. Respondents were asked to give basic demographic information on their partner, such as age and employment status.

(2) Tolerant Attitudes Regarding Abuse against Women. We asked respondents about their tolerance levels toward violence against women. Based on the aforementioned "details of abusive behaviors", 19 items were generated for this section as follows: "No abuse can be overlooked $=0$ ", "Abuse can be tolerated in certain unavoidable situations $=1$ " and "Permissible behavior between a married couple or boyfriend and girlfriend $=2$ ". The sum total was called "Total for tolerance level of abuse against women". The higher the score, the more tolerant the person was considered to be of abuse. Cronbach's alpha coefficients (alpha reliability) for "Total for tolerance level of abuse against women" was 0.82 . These items were subgrouped into three categories: "Tolerance of emotional abuse", "Tolerance of physical abuse" and “Tolerance of sexual abuse". Subscore Cronbach's alpha coefficients ranged from 0.62 to 0.67 .

(3) Degree of Satisfaction with Relationship and Degree of Attachment. Respondents' satisfaction level with their spouse/boyfriend (or girlfriend) was evaluated as the "Degree of satisfaction with relationship". Also asked was how much value the 
Table 1 Characteristic of subjects

\begin{tabular}{|c|c|c|c|}
\hline Variables & $\begin{array}{c}\text { Female }(\mathrm{N}=491) \\
\%\end{array}$ & $\begin{array}{c}\text { Male }(\mathrm{N}=397) \\
\%\end{array}$ & $\mathrm{P}^{\mathrm{a})}$ \\
\hline Age $^{\mathrm{b})}$ Mean $\pm \mathrm{SD}$ & $46.3 \pm 14.7$ & $49.8 \pm 14.4$ & $* * *$ \\
\hline Age groupings ${ }^{c)}$ & & & $* * *$ \\
\hline $18-29$ years & 13.6 & 10.8 & \\
\hline $30-39$ years & 23.2 & 14.0 & \\
\hline $40-49$ years & 21.2 & 18.7 & \\
\hline $50-59$ years & 19.8 & 25.6 & \\
\hline 60 years or above & 22.2 & 30.9 & \\
\hline Employment status ${ }^{c)}$ & & & $* * *$ \\
\hline Domestic worker & 12.2 & 19.7 & \\
\hline Full-time employee & 23.6 & 56.7 & \\
\hline Part-time worker & 21.1 & 6.1 & \\
\hline Homemaker, unemployed or student & 41.5 & 16.7 & \\
\hline No answer & 1.6 & 0.8 & \\
\hline Number of children ${ }^{\mathrm{c})}$ & & & ns \\
\hline One or more & 81.3 & 76.3 & \\
\hline None & 16.6 & 21.6 & \\
\hline No answer & 2.2 & 2.1 & \\
\hline Marital status ${ }^{\mathrm{c})}$ & & & $* * *$ \\
\hline Married & 73.9 & 78.1 & \\
\hline Single \& have boyfriend/girlfriend & 6.9 & 7.7 & \\
\hline Divorced, widowed & 13.6 & 4.7 & \\
\hline Single & 5.3 & 9.5 & \\
\hline No answer & 0.2 & 0.0 & \\
\hline Household type $e^{c)}$ & & & ns \\
\hline Single person household & 5.7 & 8.4 & \\
\hline Husband/wife or couple & 16.3 & 20.3 & \\
\hline Nuclear family household & 33.2 & 32.7 & \\
\hline Parents/other adult including spouse/lover & 20.6 & 19.0 & \\
\hline Parents/other adult excluding spouse/lover & 22.4 & 15.8 & \\
\hline No answer & 1.8 & 3.8 & \\
\hline Employment status of partner ${ }^{c}$ & & & $* * *$ \\
\hline Self-employed worker & 16.9 & 12.7 & \\
\hline Full-time employee & 48.7 & 12.4 & \\
\hline Part-time worker & 3.7 & 21.1 & \\
\hline Homemaker, unemployed \& student & 11.2 & 37.7 & \\
\hline No answer & 19.5 & 16.1 & \\
\hline Age difference between self and partner ${ }^{\mathrm{b}) \mathrm{d})}$ & $(\mathrm{N}=397)$ & $(\mathrm{N}=325)$ & ns \\
\hline Mean $\pm \mathrm{SD}$ & $3.0 \pm 2.9$ & $3.2 \pm 3.0$ & \\
\hline
\end{tabular}

a ) ${ }^{*} \mathrm{P}<0.05,{ }^{* *} \mathrm{P}<0.01,{ }^{* *} \mathrm{P}<0.001$, ns : not significant.

b ) $\mathrm{t}$-test.

c) $\chi^{2}$ test.

d ) Limited to those with spouse/boyfriend or girlfriend.

respondents placed on their relationship with their spouse/boyfriend (or girlfriend) on a day-to-day basis. Based on previous studies (Griffin and Bartholomew, 1994 ; Inaba, 1995), information was sought on the "Degree of attachment" that respondents felt with the spouse/boyfriend (or girlfriend). Questionnaire items regarding sense of attachment were phrased in the following manner : 
Table 2 Composition and confidence coefficients of scales used for independent variables

\begin{tabular}{|c|c|c|c|c|c|c|c|}
\hline Scales & Items & Categories & Range & $\begin{array}{c}\text { Cronbach's } \\
\text { alpha }\end{array}$ & $\begin{array}{c}\text { Female } \\
(\mathrm{N}=491) \\
\text { Mean } \pm \mathrm{SD}\end{array}$ & $\begin{array}{c}\text { Male } \\
(\mathrm{N}=397) \\
\text { Mean } \pm \text { SD }\end{array}$ & $\mathrm{P}^{\mathrm{a})}$ \\
\hline Total for tolerance level of abuse against women & 19 & 3 & $0-38$ & 0.82 & $4.15 \pm 3.37$ & $4.84 \pm 3.84$ & $* *$ \\
\hline Tolerance of emotional abuse & 9 & 3 & $0-18$ & 0.67 & $3.29 \pm 2.31$ & $3.71 \pm 2.48$ & ns \\
\hline Tolerance of physical abuse & 7 & 3 & $0-14$ & 0.62 & $0.22 \pm 0.95$ & $0.31 \pm 0.88$ & $* *$ \\
\hline Tolerance of sexual abuse & 3 & 3 & $0-6$ & 0.67 & $0.70 \pm 1.32$ & $0.80 \pm 1.30$ & ns \\
\hline Degree of satisfaction with relationship ${ }^{\mathrm{b})}$ & 1 & 5 & $1-5$ & - & $3.80 \pm 1.03$ & $4.14 \pm 0.79$ & $* * *$ \\
\hline Degree of attachment $t^{\mathrm{b})}$ & 8 & 4 & $0-24$ & 0.84 & $14.84 \pm 5.01$ & $15.93 \pm 4.72$ & $* *$ \\
\hline View of traditional gender roles & 5 & 4 & $0-15$ & 0.71 & $5.59 \pm 2.27$ & $7.09 \pm 2.66$ & $* * *$ \\
\hline View of traditional married relationships & 3 & 4 & $0-9$ & 0.67 & $3.64 \pm 1.90$ & $4.43 \pm 1.90$ & $* * *$ \\
\hline Reluctance to disclose marital problems & 3 & 4 & $0-9$ & 0.88 & $4.88 \pm 2.05$ & $5.36 \pm 1.82$ & $* * *$ \\
\hline Image of family in childhood & 8 & 4 & $0-24$ & 0.82 & $17.92 \pm 4.93$ & $18.22 \pm 3.67$ & ns \\
\hline
\end{tabular}

a ) t-test ${ }^{*} \mathrm{P}<0.05,{ }^{* *} \mathrm{P}<0.01,{ }^{* * *} \mathrm{P}<0.001$, ns : not significant.

b ) Limited to those with spouse/boyfriend or girlfriend.

“one's spouse/boyfriend (or girlfriend) is one's anchor" or "the respondent misses spouse/boyfriend (or girlfriend) when we are not together". A 4point scale was employed as follows: "always $=3$ ", "most of the time $=2$ ", "sometimes $=1$ " and "never $=0$ ". Scores were added to yield a total score ; the alpha reliability coefficient was 0.84 .

(4) Views of Traditional Gender Roles, Traditional Married relationships, and Reluctance to Disclose Marital Problems. Drawing on previous studies undertaken in Western nations and Japan (Bem, 1981 ; Suzuki, 1991), we generated 11 items on respondents' "View of traditional gender roles", "View of traditional married relationships", and "Reluctance to disclose marital problems". A 4point scale was generated as follows: "Strongly disagree $=0$ ", "Somewhat disagree $=1$ ", "Somewhat agree $=2$ " and "Strongly agree $=3$ ". Scores were added to yield a total score; the alpha reliability coefficient for these scales ranged from 0.67 to 0.88 .

(5) Image of Family in Childhood. Referring to previous studies on violence and abuse (Rosenbaum and O'Leary, 1981 ; Briere and Runtz, 1989 ; Jewkes et al., 2002), we presented 8 statements on how the subjects evaluated their childhood fam- ily situation, including the presence of abuse in the family and experience of being bullied during their elementary and junior high school years. Of special concern was whether the respondent's father had been violent against his/her mother and/or whether the respondent had been beaten by his/ her parents. A 4-point scale was employed as follows : "Always $=3$ ", "Often $=2$ ", "Sometimes $=1$ " and "Never $=0$ ". The higher the total score, the less favorable was the family experience of the subject during childhood. The alpha reliability coefficient for this scale was 0.82 .

(6) Women's Reaction to Abuse. Respondents who had experienced abuse were asked whether they had sought counseling and/or support, and, if so, the name of the institution/person she consulted, or conversely, the reason she had not sought counseling/support.

\section{Data Analysis}

Descriptive statistics were used to analyze the demographic patterns of DV and abuse for both men and women. The reactions of women to the experience of abuse were examined.

In addition, in an effort to explain the degree and frequency of $\mathrm{DV}$, we performed multiple regression 
analysis using the degree of abuse as the dependent variable and logistic regression analysis using frequency of abuse as the dependent variable. Independent variables are shown in Table 2.

The SPSS standard version 11.5J for Windows was used for statistical analysis. Difference with $\mathrm{P}$ value less than 0.05 were considered statistically significant.

\section{Results}

1. Abuse against Women in the 12 Months Preceding the Survey

1) Women's Experience of Domestic Violence (Table 3)

Of the female respondents, $30.1 \%$ reported experiencing abuse at least once in the 12 months preceding the survey. Emotional abuse was reported by $29.6 \%$ of female respondents, physical abuse by $5.4 \%$ and sexual abuse by $6.2 \%$. Repeated emotional abuse was reported by $9.2 \%$ of all of the female respondents, repeated physical abuse by $0.4 \%$, and repeated sexual abuse by $1.0 \%$.

Survey items that correlated with a relatively high prevalence of abuse were : "My husband/boyfriend degraded me by making a nasty comment" $(15.9 \%)$, "I was completely ignored by my husband/boyfriend no matter what I said" (14.1\%), and "My husband/boyfriend ordered me in an angry tone to do something" (12.7\%). In the category of physical abuse, "My husband/boyfriend slapped/hit/kicked me" (4.3\%) was the item with the highest positive response rate. In reference to sexual abuse, the item with the highest positive response rate was "My husband/boyfriend coerced me into unwanted sexual behavior" (4.9\%). These items also tended to be indicated as repeated behavior.
2) Men's Experience of Committing Abuse against Women (Table 3)

Of all male respondents, $34.6 \%$ answered they had "abused a woman" in the last 12 months. According to the type of abuse, $32.3 \%$ reported committing emotional abuse, $4.1 \%$ physical and $4.9 \%$ sexual abuse. Repeated emotional abuse was committed by $2.5 \%$, repeated physical abuse by $0.3 \%$ and repeated sexual abuse by $0.8 \%$.

Items on emotional abuse with a high positive response rate included : "I completely ignored my wife/girlfriend no matter what she said" (21.2\%), "I degraded my wife/girlfriend by making a nasty comment" (14.5\%) and "I ordered my wife/girlfriend in an angry tone to do something" (13.7\%). The highest positive response rate among the items on physical abuse was to the statement "I slapped/hit/kicked my wife/girlfriend" (3.9\%). "I was reluctant to use a condom" (2.6\%) and "I coerced my wife/girlfriend into unwanted sexual behavior" (2.3\%) also received the higher percentages of positive responses. When positive responses rates for these types of abuse were high, repeated abuse also tended to be indicated at a higher rate.

The frequency with which women reported experiencing emotional, physical and sexual abuse did not differ significantly from the frequency with which men reported committing such abuse.

3) Patterns of DV Commission or Experience by Sex (Table 4)

We examined patterns of DV from the viewpoint of women (as the abused) and men (as abusers). Table 4 shows patterns of abuse by abuse type and sex.

Of abused women, $96.5 \%$ answered they had been emotionally abused. Of these, $30.3 \%$ were physically and/or sexually abused as well. Of men with a history of committing abuse, 95.4\% answered they had emotionally abused women. Of 
Table 3 Experiences of women being abused and men abusing in the past 12-months

\begin{tabular}{|c|c|c|c|c|}
\hline \multirow[b]{2}{*}{$\begin{array}{l}\text { Abusive Behaviors by Episode } \\
\text { (statements in parenthesis applied to men) }\end{array}$} & \multicolumn{2}{|c|}{ Female $(\mathrm{N}=491)$} & \multicolumn{2}{|c|}{ Male $(\mathrm{N}=397)$} \\
\hline & $\begin{array}{l}\text { single } \\
\text { experience } \\
\%\end{array}$ & $\begin{array}{l}\text { multiple } \\
\text { experiences } \\
\%\end{array}$ & $\begin{array}{l}\text { single } \\
\text { experience } \\
\%\end{array}$ & $\begin{array}{c}\text { multiple } \\
\text { experiences } \\
\%\end{array}$ \\
\hline \multicolumn{5}{|l|}{ Emotional abuse } \\
\hline $\begin{array}{l}\text { I was completely ignored by my husband/boyfriend no matter what I said. } \\
\text { (I completely ignored my wife/girlfriend no matter what she said.) }\end{array}$ & 14.1 & 3.3 & 21.2 & 2.1 \\
\hline $\begin{array}{l}\text { I was spied on by my husband/boyfriend regarding my social life with } \\
\text { family and/or friends. (I spied on my wife/girlfriend regarding her social } \\
\text { life.) }\end{array}$ & 4.1 & 1.2 & 2.3 & 0.3 \\
\hline $\begin{array}{l}\text { Belongings that I cherished were intentionally broken or thrown away by } \\
\text { my husband/boyfriend. (I intentionally broke or threw away my wife/ } \\
\text { girlfriend's belongings that she cherished.) }\end{array}$ & 2.4 & 0.6 & 1.0 & 0.5 \\
\hline $\begin{array}{l}\text { I was told by my husband/boyfriend, "Who do you think feeds you?" (I } \\
\text { told my wife/girlfriend, "Who do you think feeds you?") }\end{array}$ & 4.5 & 0.4 & 3.1 & 1.0 \\
\hline $\begin{array}{l}\text { My husband/boyfriend degraded me by making a nasty comment. (I } \\
\text { degraded my wife/girlfriend by making a nasty comment.) }\end{array}$ & 15.9 & 3.3 & 14.5 & 2.1 \\
\hline $\begin{array}{l}\text { My husband/boyfriend ordered me in an angry tone to do something. (I } \\
\text { ordered my wife/girlfriend in an angry tone to do something.) }\end{array}$ & 12.7 & 3.9 & 13.7 & 1.6 \\
\hline $\begin{array}{l}\text { My husband/boyfriend does/did not allow me to manage the family } \\
\text { budget. (I do/did not allow my wife/girlfriend to manage the family } \\
\text { budget.) }\end{array}$ & 3.4 & 1.4 & 0.5 & 0.5 \\
\hline $\begin{array}{l}\text { My husband/boyfriend does/did not allow me to work. (I want my wife/ } \\
\text { girlfriend to stay at home and do/did not allow her to work.) }\end{array}$ & 2.2 & 0.2 & 1.0 & 0.0 \\
\hline $\begin{array}{l}\text { My husband/boyfriend threatened me verbally and/or by physical } \\
\text { gestures. (I threatened my wife/girlfriend verbally and/or by physical } \\
\text { gestures.) }\end{array}$ & 7.9 & 1.8 & 6.5 & 0.5 \\
\hline Respondents with repeated episodes of emotional abuse & 29.6 & 9.2 & 32.3 & 2.5 \\
\hline \multicolumn{5}{|l|}{ Physical abuse } \\
\hline $\begin{array}{l}\text { My husband/boyfriend threw an object that could hurt me (I threw an } \\
\text { object that could hurt my wife/girlfriend). }\end{array}$ & 2.2 & 0.0 & 0.5 & 0.3 \\
\hline $\begin{array}{l}\text { My husband/boyfriend slapped/hit/kicked me. (I slapped/hit/kicked my } \\
\text { wife/girlfriend.) }\end{array}$ & 4.3 & 0.2 & 3.9 & 0.3 \\
\hline $\begin{array}{l}\text { My husband/boyfriend hit me with an object that could hurt me. (I hit } \\
\text { my wife/girlfriend with an object that could hurt her.) }\end{array}$ & 0.8 & 0.2 & 0.8 & 0.3 \\
\hline My husband/boyfriend choked me. (I choked my wife/girlfriend.) & 0.8 & 0.2 & 0.3 & 0.3 \\
\hline $\begin{array}{l}\text { My husband/boyfriend pointed a knife at me. (I pointed a knife at my } \\
\text { wife/girlfriend.) }\end{array}$ & 0.2 & 0.2 & 2.3 & 0.0 \\
\hline $\begin{array}{l}\text { My husband/boyfriend injured me with a weapon. (I injured my wife/girl- } \\
\text { friend with a weapon.) }\end{array}$ & 0.2 & 0.0 & - & - \\
\hline $\begin{array}{l}\text { The injury caused by my husband/boyfriend required medical attention. } \\
\text { (My wife/girlfriend's injury that I caused required medical attention.) }\end{array}$ & 0.4 & 0.0 & - & - \\
\hline Respondents with repeated episodes of physical abuse & 5.4 & 0.4 & 4.1 & 0.3 \\
\hline \multicolumn{5}{|l|}{ Sexual abuse } \\
\hline $\begin{array}{l}\text { My husband/boyfriend coerced me into looking at a pornographic video } \\
\text { or magazine. (I coerced my wife/girlfriend into looking at a pornographic } \\
\text { video or magazine.) }\end{array}$ & 0.4 & 0.2 & 1.6 & 0.3 \\
\hline $\begin{array}{l}\text { My husband/boyfriend is/was reluctant to use a condom to prevent } \\
\text { unwanted pregnancy. (I was reluctant to use a condom.) }\end{array}$ & 2.4 & 0.2 & 2.6 & 0.8 \\
\hline
\end{tabular}


Table 3 Experiences of women being abused and men abusing in the past 12-months

\begin{tabular}{|c|c|c|c|c|}
\hline \multirow[b]{2}{*}{$\begin{array}{l}\text { Abusive Behaviors by Episode } \\
\text { (statements in parenthesis applied to men) }\end{array}$} & \multicolumn{2}{|c|}{ Female $(\mathrm{N}=491)$} & \multicolumn{2}{|c|}{ Male $(\mathrm{N}=397)$} \\
\hline & $\begin{array}{c}\text { single } \\
\text { experience } \\
\%\end{array}$ & $\begin{array}{c}\text { multiple } \\
\text { experiences } \\
\%\end{array}$ & $\begin{array}{c}\text { single } \\
\text { experience } \\
\%\end{array}$ & $\begin{array}{c}\text { multiple } \\
\text { experiences } \\
\%\end{array}$ \\
\hline $\begin{array}{l}\text { My husband/boyfriend coerced me into unwanted sexual behavior. (I } \\
\text { coerced my wife/girlfriend into unwanted sexual behaviors.) }\end{array}$ & 4.9 & 1.0 & 2.3 & 0.8 \\
\hline Respondents with repeated of sexual abuse & 6.2 & 1.0 & 4.9 & 0.8 \\
\hline Respondents with episodes of cross-category abuse & 30.1 & 9.6 & 34.6 & 5.8 \\
\hline
\end{tabular}

Note : Individual percentages of men and women, excluding those failing to answer.

Table 4 Abuse patterns by sex

\begin{tabular}{lcc}
\hline & Female & Male \\
& $(\mathrm{N}=142)$ & $(\mathrm{N}=131)$ \\
& $\%$ & $\%$ \\
\hline Emotional abuse only & 66.2 & 75.6 \\
Emotional \& physical & 10.6 & 6.8 \\
Emotional \& sexual & 14.1 & 10.7 \\
Emotional, physical \& sexual & 5.6 & 2.3 \\
Physical abuse only & 2.1 & 3.1 \\
Sexual abuse only & 1.4 & 1.5 \\
Physical \& sexual & 0.0 & 0.0 \\
\hline
\end{tabular}

these men, $19.8 \%$ had physically and/or sexually abused women.

Few respondents answered they had experienced or committed solely physical or sexual abuse ; in other words, emotional abuse, in most cases, was accompanied by either physical and/or sexual abuse.

4) Lifetime Abuse Experience

With regard to lifetime experience of abuse, $54.8 \%$ of women and $61.5 \%$ of men answered that they had at some point either experienced (women) or committed (men) some type of abuse.

Of the $53.6 \%$ of women who had experienced emotional abuse, $23.5 \%$ also experienced physical and $20.6 \%$ experienced sexual abuse. Regarding repeated abuse over their lifetime, $22.6 \%$ of women reported repeated emotional, 5.1\% repeated physical and $6.3 \%$ repeated sexual abuse.
Among male respondents, 58.7\% answered that they had committed emotional abuse, $18.3 \%$ physically abuse and $17.1 \%$ sexually abuse. As for repeated abuse, $22.6 \%$ of men who had emotionally abused women repeatedly inflicted emotional abuse. For repeated physical abuse and sexual abuse over a lifetime, the percentages were $5.1 \%$, and $1.4 \%$, respectively.

\section{Factors Correlating with the Experience of Abuse by Women in the 12 Months Preceding Survey (Table 5)}

Multiple regression analysis was used to examine factors related to the degree of DV. We observed that having experienced abuse in the home environment as a child was correlated with an increased likelihood of a woman being abused as an adult (standardized regression coefficient $(\beta)=-0.095, \mathrm{P}<0.01)$. The higher the degree of satisfaction a woman had with her partner, the less likely she was to be abused $(\beta=-0.255, \mathrm{P}<$ 0.001). The lower the degree of attachment the woman felt for her partner, the more likely she was to be abused $(\beta=-0.226, \mathrm{P}<0.001)$.

Next, we examined factors related to the experience of each type of abuse using logistic regression analysis. In the emotional abuse category, subjects with a high degree of satisfaction with their current relationship were less likely to be abused 


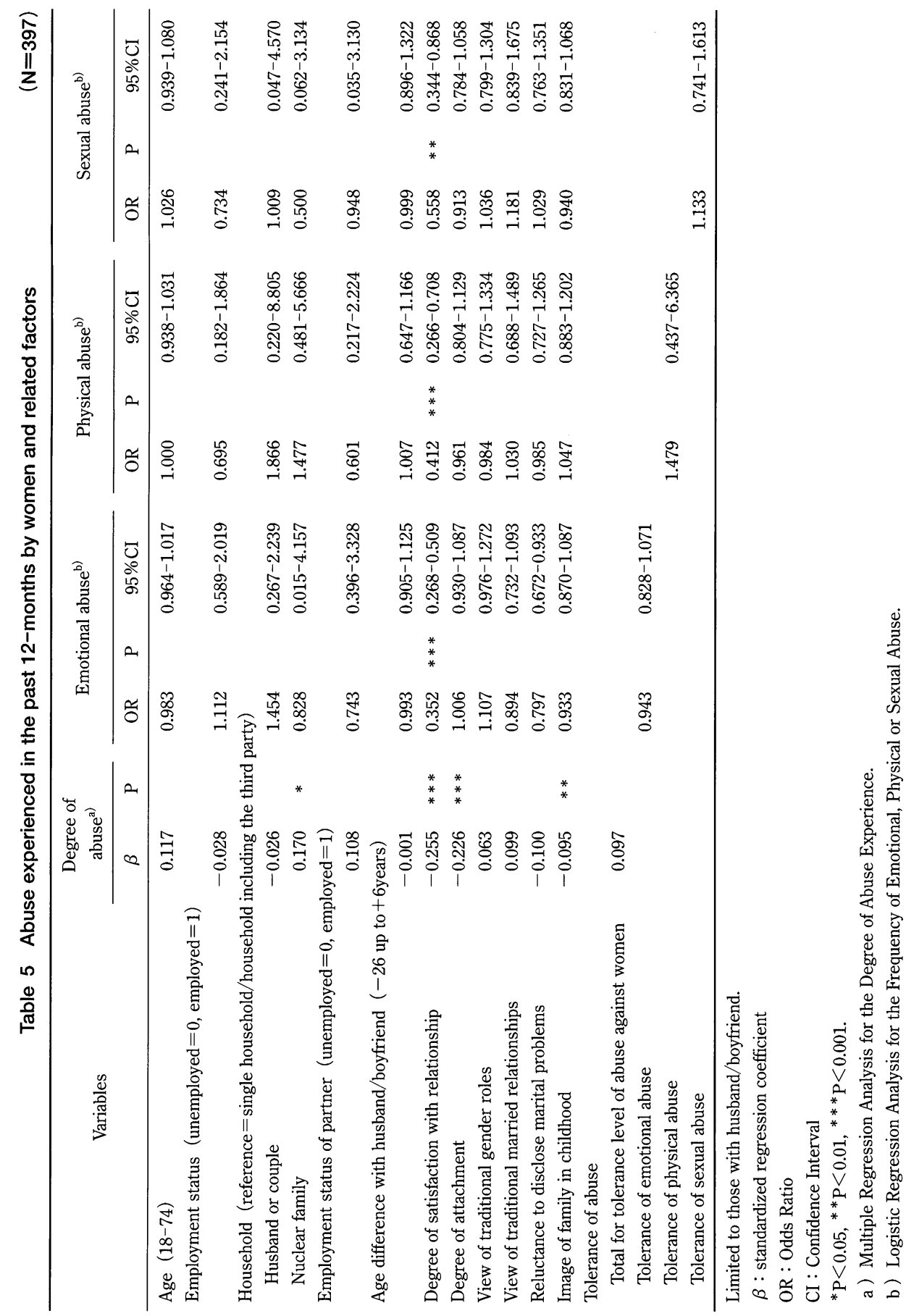


(Odds Ratio $(\mathrm{OR})=0.352 ; 95 \%$ Confidence Interval $(95 \% \mathrm{CI})=0.268-0.509)$. In the physical and sexual abuse category, the higher the degree of satisfaction a woman felt with her partner, the less likely she was to be abused $(\mathrm{OR}=0.412 ; 95 \%$ $\mathrm{CI}=0.266-0.708, \quad \mathrm{OR}=0.558 ; 95 \% \quad \mathrm{CI}=0.344-$ $0.868)$.

\section{Abuse Committed by Men within the $\mathbf{1 2}$} Months Preceding the Survey and Related Factors (Table 6)

We examined factors related to the degree of DV using multiple regression analysis. Men with fulltime employment tended to be more abusive $(\beta=$ $0.122 ; \mathrm{P}<0.05)$. When the age difference between a man and his wife/girlfriend was increased $(\beta=-0.111 ; \mathrm{P}<0.05)$ and when men experienced a relatively abuse-free home environment as children $(\beta=-0.112 ; \mathrm{P}<0.05)$, there was a tendency to report less abuse. Men reporting a higher degree of satisfaction with their relationship were less likely to be abusive ( $\beta=$ $-0.187, \mathrm{P}<0.01)$. The more tolerant subjects were of abusive behavior, the more likely they were to engage in such behavior $(\beta=0.280, \mathrm{P}<$ 0.01 ).

Factors correlating with DV by type of abuse were subjected to logistic regression analysis. Subjects with a higher degree of attachment to their partner were less likely to be emotionally abusive $(\mathrm{OR}=0.918,95 \% \mathrm{CI}=0.859-0.980)$. Men in a nuclear family situation, married men with children $(\mathrm{OR}=7.561,95 \% \mathrm{CI}=0.849-54.144)$, and men with a large age discrepancy compared with their wife/girlfriend $(\mathrm{OR}=0.797,95 \% \mathrm{CI}=0.691-1.005)$ tended to be more sexual abusive. In all 3 categories, subjects reporting tolerant attitudes toward DV tended to be more abusive $(\mathrm{OR}=1.225,95 \% \mathrm{CI}=$ $1.115-1.397 ; \mathrm{OR}=1.483,95 \% \mathrm{CI}=1.095-3.045$; $\mathrm{OR}=1.680,95 \% \mathrm{CI}=1.135-2.376)$.

\section{Reactions of Women to Abuse (Table 7)}

We asked female subjects if they had consulted with someone or an institution(s) after being abused by their husband/boyfriend in the last 12 months. The percentage of women who responded affirmatively was $53.0 \%$. There was no significant difference in consultation experience by type of abuse. Consultation experience also did not correlate with the respondent's demographics such as age, profession or type of household. Furthermore, there was no correlation with "Reluctance to disclose marital problems" or "Tolerance of abuse".

Of those women who sought assistance, $46.3 \%$ reported consulting with "Immediate family", followed in frequency by "Friends and/or colleagues" (44.4\%). Only $9.3 \%$ said they had consulted with organizations such as police, counseling centers, shelters, etc. There was no correlation between type of abuse and pattern of consultation.

Of the abused women, $47.0 \%$ said they had spoken with no one about their abuse. The reasons cited were belief that the abuse was not serious (72.0\%), embarrassment (9.9\%) and lack of expectation that the consultation would be productive (9.9\%).

Regarding women's' relationship with their partner after the abusive episode(s), $7.3 \%$ said they "broke up/divorced" while $47.6 \%$ indicated "I thought about breakup/divorce but didn't" and 45.1\% selected "I did not think about breakup/ divorce". When women had suffered only emotional abuse, $58.0 \%$ stated that they did not consider breakup or divorce. However, when emotional abuse occurred along with physical or sexual abuse, women were more likely to want to end the relationship ; in such cases, $71.1 \%$ of women stated that they considered breaking up or divorcing. 
Jpn J Health \& Human Ecology

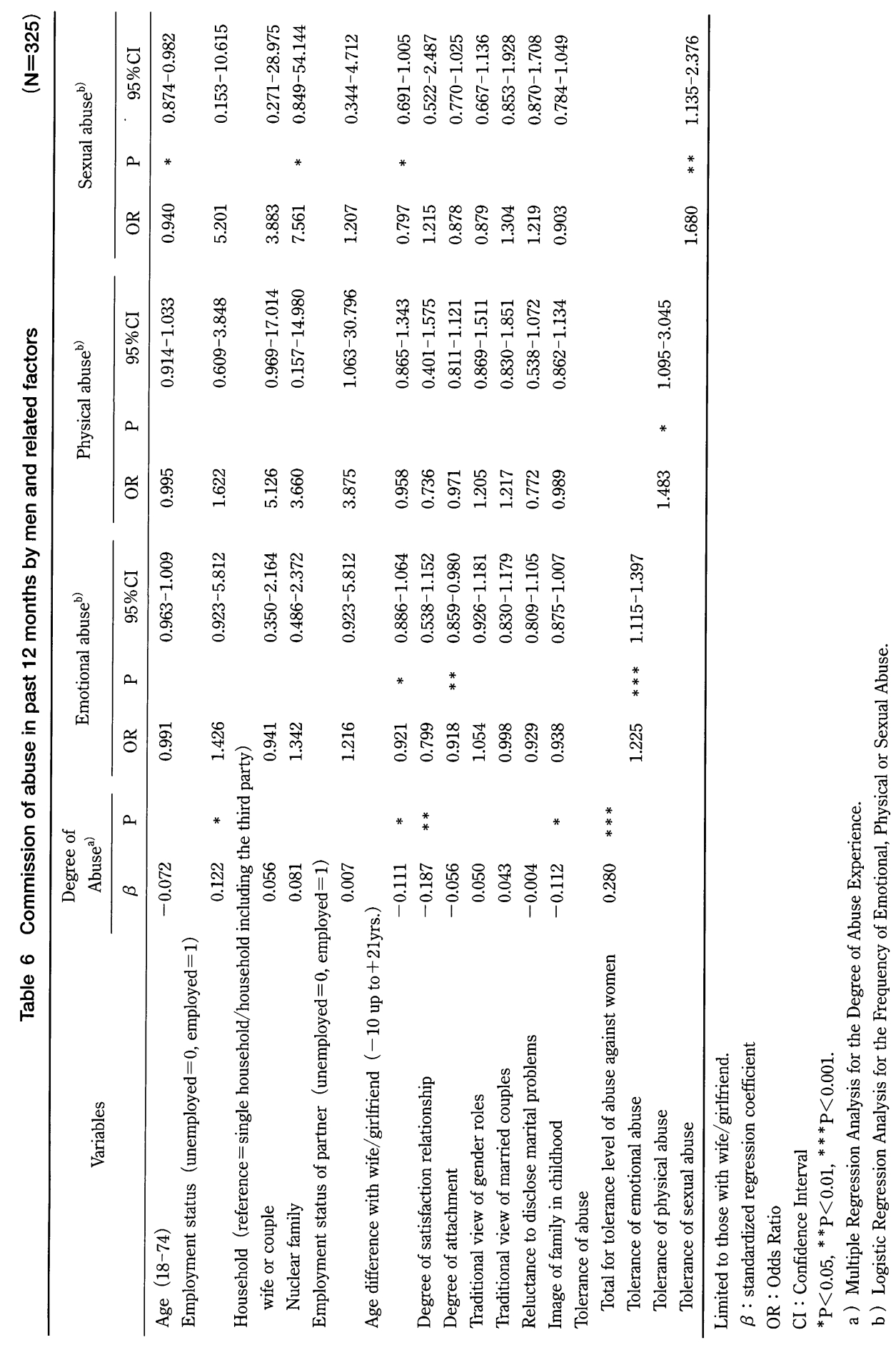


Table 7 Reactions of women to abuse

\begin{tabular}{|c|c|c|c|c|c|}
\hline & $\begin{array}{c}\text { Total } \\
(\mathrm{N}=142) \\
\%\end{array}$ & $\begin{array}{c}\text { Emotional } \\
\text { only }\end{array}$ & $\begin{array}{c}\text { Emotional, } \\
\text { and } \\
\text { physical } \\
\text { and/or } \\
\text { sexual } \\
(\mathrm{N}=43) \\
\%\end{array}$ & $\begin{array}{l}\text { Physical } \\
\text { or sexual }\end{array}$ & $\mathrm{P}^{\mathrm{a})}$ \\
\hline \multicolumn{6}{|l|}{ Consultation } \\
\hline Yes & 53.0 & 52.9 & 58.3 & 50.0 & ns \\
\hline No & 47.0 & 47.1 & 41.7 & 50.0 & ns \\
\hline \multicolumn{6}{|l|}{ Person (s) consulted with $\left.{ }^{b}\right)$} \\
\hline Immediate family & 46.3 & 49.3 & 40.0 & 50.0 & ns \\
\hline Friends and/or colleagues & 44.4 & 42.0 & 48.6 & 50.0 & ns \\
\hline Public institutions & 9.3 & 8.7 & 11.4 & 0.0 & ns \\
\hline \multicolumn{6}{|l|}{ Reasons for not consulting ${ }^{\text {b) }}$} \\
\hline Abuse not that serious & 72.0 & 88.6 & 40.0 & 100.0 & $* * *$ \\
\hline Embarrassment & 9.9 & 4.6 & 20.0 & 0.0 & $*$ \\
\hline Feel there is no point in seeking help & 9.9 & 6.8 & 16.0 & 0.0 & ns \\
\hline Fear that abuse will be exacerbate & 5.5 & 0.0 & 16.0 & 0.0 & $* *$ \\
\hline Hate to go through an unpleasant experience & 2.7 & 0.0 & 8.0 & 0.0 & ns \\
\hline Relationship w husband/boyfriend after abuse & & & & & $* *$ \\
\hline Broke up/divorced & 7.3 & 6.2 & 10.5 & 0.0 & \\
\hline Thought about breakup/divorce but did not & 47.6 & 35.8 & 71.1 & 60.0 & \\
\hline Did not think about breakup/divorce & 45.1 & 58.0 & 18.4 & 40.0 & \\
\hline
\end{tabular}

Note : Excluding unanswered questionnaires.

a ) $\chi^{2}$ test ${ }^{*} \mathrm{P}<0.05,{ }^{* *} \mathrm{P}<0.01,{ }^{* * *} \mathrm{P}<0.001, \mathrm{~ns}$ : not significant.

b ) Multiple answered.

\section{Discussion}

\section{Context of This Study}

In the past, surveys on DV in Japan have been conducted in major cities like Tokyo, Nagoya and Sapporo. This study involved smaller municipalities with a total population of two million, which makes this study important in terms of observing trends across the nation in regions other than large cities.

The lifetime prevalence of abuse against women identified in this study was $53.6 \%$ for emotional abuse, $23.5 \%$ for physical abuse, and $20.6 \%$ for sexual abuse. Although the content of the questionnaire and the study population were somewhat different from those in other studies, the findings are very similar. For example, according to a 1997 sur- vey of women in Tokyo between the ages of 20 to 64 years, $55.9 \%$ had experienced emotional abuse, $33.0 \%$ physical abuse and $20.9 \%$ sexual abuse (Tokyo Metropolitan Government, 1998). Regardless of the type of abuse, between 20 and $30 \%$ of this abuse occurred repeatedly. Judging from these findings, the prevalence of DV will likely show similar trends in other regions of Japan.

\section{Distribution of Abuse of Women and Analysis}

Previous studies have generally focused on the lifetime prevalence of DV (Tokyo Metropolitan Government, 1998 ; Japanese Prime Minister's Office, 2000 ; Nagoya City General Affairs Office, 2000). In this study, we examined the incidence of abuse within a 12-month time period. Our goal 
was to come up with more accurate data on the actual state of DV in Japan. According to our results, there was no discrepancy between the frequency of women experiencing abuse and the proportion of men who reported committing abuse : these percentages were, for emotional abuse, $30 \%$, physical abuse, $4-5 \%$, and sexual abuse, 5$6 \%$ for both sexes. In other words, approximately 1 out of 3 women had experienced emotional abuse and 1 out of 20 women had experienced physical or sexual abuse. These data more properly reflect the current state of $\mathrm{DV}$, and it is hoped that this information will prompt the undertaking of effective measures against DV.

In examination of patterns of DV, physical and/ or sexual abuse were found to be accompanied by emotional abuse in many cases. Since this is a cross-sectional study, a causal relationship cannot be determined ; however, it is possible that emotional abuse is a forerunner of physical and/or sexual abuse. According to the definition of violence against women adopted at the 2000 United Nations Conference in New York, emotional abuse against women must be included in the general category of DV against women. Internationally, the trend is to regard emotional abuse as violent behavior. Thus, we Japanese as well must pay closer attention to the topic of emotional abuse.

However, it is also true that the definition of "Emotional abuse" has yet to be fully established and needs further discussion. In this study, we concluded that it was appropriate to consider any positive response to items on the questionnaire in the category of emotional abuse as an example of DV. Specifically, when items such as "I was completely ignored by my husband/boyfriend no matter what I said" or "My husband/boyfriend ordered me in an angry tone to do something" were marked affirmatively, we counted this as an occurrence of DV. In case of emotional abuse, the significance of experi- encing one's partner's cold manner and/or harsh language should not be underestimated. At the same time, we must be careful not to confuse DV with borderline everyday events or behavior. Therefore, in order to stop and/or prevent DV more effectively, further discussion on DV must to be undertaken to better define DV according to the current cultural climate.

\section{Factors Related to Violence against Women}

In this study, we focused on 7 socio-psychological factors identified to be associated with DV by previous investigations in Europe and the United States and examined their association with DV in our Japanese subjects.

The factors most strongly associated with DV against women were: the degree of satisfaction with the relationship, degree of attachment to one's partner, and one's experience of abuse in one's childhood family environment. Among these factors, the degree of satisfaction with one's relationship had a strong negative association with DV. The tendencies we identified were similar to those observed in previous studies, which also indicated that a good relationship with one's wife/girlfriend can deter violence (Sagrestano et al., 1999 ; Dutton, 1995), and that abusive experiences in childhood/adolescence may later trigger intergenerational chains of abuse (Dutton, 1995 ; Barnett and Fagan, 1993 ; O'Leary and Curley, 1986 ; Rosenbaum and O'Leary, 1981 ; Marinheiro et al., 2006). We found no statistically significant difference between tolerance of DV on the part of women and experience of DV by those women. However, it is possible that women's tolerant attitudes towards DV relate to escalation of abuse. By allowing abuse to continue, some women may become used to it. In so doing, they may inadvertently keep their most serious problems unexposed. 
We did not observe any significant correlation between DV and respondents' "View of traditional gender roles", "View of traditional married relationships" and "Reluctance to disclose marital problems". Although we cannot deny the possibility that these factors are remote causes of DV, we failed to observe clear associations in this study. Further studies regarding causative factors and associations are needed.

Factors related to the frequency of commission of abuse by men were the experience of abuse in one's home environment as a child, degree of satisfaction with one's relationship, and degree to which one holds tolerant attitudes regarding abuse. In terms of strength of the correlation, the most influential factor was a tolerant attitude towards abuse, followed by the degree of satisfaction with one's relationship and one's experience of abuse in one's childhood environment. A tolerant attitude on the part of respondents towards DV was associated with an increased frequency of committing (men) or experiencing (women) DV. Given that tolerant attitudes towards DV appear to be a risk factor for DV, it is important to increase awareness of DV issues among men and women in Japanese society. As was the case with our data from women respondents, our data from male respondents suggested that a good relationship with one's partner may deter violence and that having experienced abuse in one's family environment in childhood/ adolescence may later trigger an intergenerational chain of abuse.

\section{Practical Suggestions}

Similar to the results of previous studies (Tokyo Metropolitan Government, 1998 ; Japanese Prime Minister's Office, 2000 ; Nagoya City General Affairs Office, 2000), half of abused women sought help or assistance by consulting with an individual or organization. On the other hand, a number of abused women were unwilling to "come out", due to embarrassment or fear that seeking help will be fruitless. For this reason, it is necessary to establish groups or institutions more accessible for consultation by women.

Our study showed that over $70 \%$ of women who experience a combination of emotional abuse with physical and/or sexual abuse wanted to leave their partner, but did not; we presume many of those women continue to suffer abuse.

In Europe and the United States, training and educational programs for abusive men have long been implemented (Sagrestano et al., 1999; Sonkin and Durphy, 1989 ; Hamberger and Hastings, 1988 ; Hamberger and Hastings, 1989). It is important to educate men on this issue and make them fully aware of the significance of their behavior. Meanwhile, it is also important that we provide women with educational opportunities in relation to $\mathrm{DV}$; in particular, we should strive to educate those women who hold tolerant attitudes regarding being the victim of DV.

Furthermore, we understand that it will not be enough merely to focus on supporting DV victims and finding preventive measures and/or solutions ; we must also reexamine our society, in which DV is often tolerated on various levels.

\section{Limitations and Future Directions}

Our study has several limitations. Firstly, since we targeted the general population of prefectural residents as research subjects, it is quite possible that victims of serious DV did not or could not return the questionnaire. The present study examined a sample of the general population rather than specifically focusing on women and men known to be involved in DV. Hence, our ability to focus on and examine risk factors for DV and the characteristics of those who commit or suffer abuse may have been diluted. Secondly, our study suggested 
that abusive behavior evolves from emotional abuse into physical and/or sexual abuse ; however, we had neither the time nor the means to probe this process.

With the above two points in mind, we need to analyze, from the standpoints of both men and women, factors that cause DV against women and the process by which violence intensifies and changes. It will be important to conduct in-depth personal interviews so that we will be able to better understand why two intimately involved people, a man and a woman, perceive violence in different ways.

\section{Conclusions}

1. Of the women who experienced some form of abuse in the 12 months preceding the survey, approximately $30 \%$ experienced emotional abuse, 4-5\% physical abuse and 5-6\% sexual abuse. There was no significant differences in the percentages of women who reported DV and in the percentages of men who committed DV against women.

2. Regardless of sex, approximately $90 \%$ of respondents claimed that violent behavior began with emotional abuse, which, in many cases, gradually evolved into physical and/or sexual abuse.

3. We observed a correlation between DV against women and tolerant attitudes towards abuse on the male side. In other words, the more tolerant toward violence the man was, the more likely he would abuse the woman. The greater the exposure a respondent had to abuse in his or her childhood environment, the more likely the respondent was to be abusive (men) or suffer abuse (women); this tendency suggests that that DV can be transmitted from one generation to the next.

4. Of all the abused female subjects, half had sought assistance by consulting either another individual or an organization. Most of these women merely consulted other individuals, such as family members or friends ; few consulted with organizations such as counseling centers or shelters. This highlights the importance of disseminating official information regarding DV to the general public so that victims of DV can have the information they need to seek effective help.

\section{Acknowledgments}

This research has been partly supported by a 2002 Basic Research Grant (A) from the Ministry of Education, Sports, Culture, Science and Technology. We are grateful to the staff members of the Committee on Violence Against Women of the Citizens' Life Division, Gunma Prefecture Government. Above all, we would like to thank each and every resident in Gunma who participated in our research, as well as members of the Department of Health Sociology at the University of Tokyo.

\section{References}

Bandura A (1977) : Social Learning Theory, Prentice Hall (Englewood Cliffs, New Jersey)

Barnett OW and Fagan RW (1993) : Alcohol use in male spouse abusers and their female partners, Journal of Family Violence, 8, 1-25

Beasley R and Stoltenberg CD (1992): Personality characteristics of male spouse abusers, Professional Psychology : Research and Practice, 23, 310-317

Bem SL (1981) : Gender scheme theory : A cognitive account of sex typing, Psychological Review, 88, 354364

Bensley L, Van Eenwyk J and Simmons KW (2003) : Childhood family violence history and women's risk for intimate partner violence and poor health, American Journal of Preventive Medicine, 2, 38-44

Berkowitz L (1993) : Aggression: Its causes, consequences, and control, Temple University Press, (Philadelphia)

Briere J and Runtz M (1989): The trauma symptom checklist (TSC-33) : Early data on a new scale, Journal of Interpersonal Violence, 4, 151-162

Caesar PL (1988) : Exposure to violence in the families-of-origin among wife abusers and maritally non- 
violent men, Violence and Victims, 3, 49-63

Domestic Violence Action and Research Group in Japan (1998) : Domestic violence: Towards the elimination of violence against women by husbands and boyfriends, Yuhikaku Publishing Co., Ltd (Tokyo) (in Japanese)

Dutton DG (1986) : Wife assaulters' explanations for assault : The neutralization of self-punishment, Canadian Journal of Behavioral Science, 18, 381-390

Dutton DG (1995a): The Domestic Assault of Women : Psychological and criminal justice perspectives, UBC Press (Vancouver)

Dutton DG (1995b): The Batterer:A psychological profile, Basic Books, (New York)

Dutton DG (1995c) : A scale for measuring propensity for abusiveness, Journal of Family Violence, 10, 203221

Dutton DG and Hemphill KJ (1992) : Patterns of socially desirable responding among perpetrators and victims of wife assault, Violence and Victims, 7, 2940

Dutton DG, Starzomski A and Ryan L (1996) : Antecedents of abusive behavior in wife assaulters, Journal of Family Violence, 11, 113-132

Fitch FJ and Papantonio A (1983) : Men who batter : some pertinent characteristics, Journal of Nervous and Mental Disease, 171, 190-192

Gelles RJ (1993) : Through a sociological lens : Social structure and family violence, Gelles RJ and Loseke DR (Eds.), Current Controversies on Family Violence, 31-46, Sage Publications (Newbury Park)

Griffin DW and Bartholomew K (1994) : The metaphysics of measurement: The case of adult attachment, Bartholomew K and Perlman D ed., Advances In Personal Relationships, Volume 5, 17-52, Jessica Kingsley Publishers (London)

Heise L (1998) : Violence against women : an integrated, ecological framework, Violence Against Women, 4, 262-290

Hamberger LK and Hastings JE (1988) : Skills training for treatment of spouse abusers : An outcome study, Journal of Family Violence, 3, 121-130

Hamberger LK and Hastings JE (1989) : Counseling male spouse abusers: Characteristics of treatment completers and dropouts, Violence and Victims, 4, 275-286

Inaba A (1995) : Social Patterns of Psychological Distress of Married Women, Comprehensive urban studies : Special edition, 56, 93-111

Japan Prime Minister's Office (Cabinet Office) (2000) : Survey on Violence between Men and Women 2000,
Gyousei Inc (Tokyo) (in Japanese)

Jewkes R, Levin J and Penn KL (2002) : Risk factors for domestic violence : findings from a South African cross-sectional study, Social Science and Medicine, 55, 1603-1617

Kantor GK and Straus MA (1989) : Substance abuse as a precipitant of wife abuse victimization, American Journal of Drug and Alcohol Abuse, 15, 173-189

Krahe B, Bieneck S and Möller I (2005) : Understanding Gender and Intimate Partner Violence from an International Perspective, Sex Roles, 52, 807-827

Marinheiro ALV, Vieira EM and de Souza L (2006) : Prevalence of violence against women users of health care services, REVISTA DE SAUDE PUBLICA, 40, 604-610

Nagoya City general affairs office (2000) : Report on the Survey of Violence against women, March 2000, Bureau of Citizens and Cultural Affairs (Nagoya) (in Japanese)

O'Leary KD and Curley $\mathrm{AD}$ (1986) : Assertion and family violence : correlates of spouse abuse, Journal of Marital and Family Therapy, 12, 281-289

Pence E and Paymar M (1993) : Education Groups for Men who Batter : The Duluth Model, Springer (New York)

Rosenbaum A and O'Leary KD (1981) : Marital violence : characteristics of abusive couples, Journal of Consulting and Clinical Psychology, 49, 63-71

Rosenbaum A and O'Leary KD (1987) : Children : the unintended victims of marital violence, American Journal of Orthopsychiatry, 51, 692-699

Sagrestano LM, Heavey CL and Christensen A (1999) : Perceived power and physical violence in marital conflict, Journal of Social Issues, 55, 65-79

Schechter S (1982) : Women and Male Violence, South End Press (Boston)

Sonkin DJ and Durphy M (1989) : Learning to Live without Violence: A handbook for men, Volcano press (Volcano, California)

Straus MA (1978) : Wife Beating : How Common and Why?, Victimology, 2 (November), 443-458

Straus MA and Gelles RJ (1990) : Physical Violence in American Families : Risk factors and adaptations to violence in 8,145 families, Transaction Books (New Brunswick, New Jersey)

Suzuki A (1991) : Predictors of women's sex role attitudes across two cultures: United States and Japan, Japanese Psychological Research, 33, 126-133

Telch C and Lindquist C (1984) : Violent versus nonviolent couples : A comparison of patterns, Psychotherapy, 21, 242-248 
Tokuza A (1999) : The Rise of the Feminist Movement in Japan, Keio University Press (Tokyo)

Tokyo Metropolitan Government (1998) : A Report on the Survey of Violence against women, Bureau of Citizens and Cultural Affairs (Tokyo) (in Japanese)

Umberson D, Anderson K and Shapiro A (1998): Domestic violence, personal control, and gender, Journal of Marriage and Family, 60, 442-452

Yllö KA (1993) : Through a feminist lens : gender, power, and violence, Gelles RJ and Loseke DR (Eds.), Current Controversies on Family Violence, 47-62, Sage publications (Newbury Park, California)

Yoshihama M (2002) : Policies and services addressing domestic violence in Japan : From non-interference to incremental changes, Women's Studies International Forum, 25, 541-553

Walker LE (1979): The Battered Woman, Harper \& Row, (New York)

Walker LE (1994) : Abused Women and Survivor Therapy:A practical guide for the psychotherapist, American Psychological Association (Washington, DC)

World Bank (1993) : World Development Report 1993 : Investing in Health, Oxford UniversityPress (Oxford) (Received 2. 24. 2007 ; Accepted 9. 18. 2007) 


\section{Prevalence of domestic violence against women and its risk factors in Gunma, Japan}

Kazumi FUJIMURA, Tohru YOSHIDA, Takeshi YAMAMOTO and Yoshihiko YAMAZAKI Jpn J Health \& Human Ecology, 73(6) 225-241, 2007

\section{和文抄録}

一般成人男女において，夫婦間・恋人間といった親密な関係にある男性からの女性への暴力発生の分布 とその関連要因を検討し, 社会的対応への示唆を得ることを目的として, 18〜 74 歳の群馬県在住の 888 名 （男性 397 名, 女性 491 名）を対象に, 調査・分析を行った.

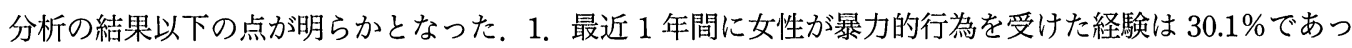
た. 行為の種類別にみると, 精神的暴力行為 $29.6 \%$, 身体的暴力行為 $5.4 \%$, 性的暴力行為 $6.2 \%$ あった. 男性においても，暴力を振るった経験はほぼ同じ結果を示した．2. 暴力の重複パターンを検討した結果， 男女とも多くの場合で身体的あるいは性的暴力行為には精神的暴力行為が伴うことが示された． 3. 女性 への璟力の関連要因として, 男性の暴力容認度, つまり暴力を容認している男性ほど暴力を振るいやすい という傾向が認められた。 また，男女とも生育家族評価が低い人ほど暴力的行為を経験している傾向が認 められた．4. 暴力的行為を受けた女性のうち，半数は誰か（どこか）に相談していた。 しかし相談先と しては, 近親者, 友人・職場関係者といったインフォーマルな関係にある人がほとんどであり, 公的機関 へ相談をしたという人はわずかであった，相談機関やシェルター等，ソーシャルサポートの充実がなされ る一方で, その利用を促すためにも, 個々人への情報の発信と一般住民の女性に対する暴力を許さない社 会の意識䁔成のための理解が不可欠であることの可能性が示唆された. 